\title{
Mapping and Analysis of Geodiversity Indices in the Xingu River Basin, Amazonia, Brazil
}

\author{
Juliana de Paula Silva • Cleide Rodrigues • \\ Diamantino Insua Pereira
}

Received: 1 April 2014 / Accepted: 2 October 2014

(C) The European Association for Conservation of the Geological Heritage 2014

\begin{abstract}
From the 1990s, geodiversity studies have been widely carried out in order to understand, describe and preserve the natural heritage of the abiotic environment. Geodiversity assessments have principally been conducted using geological (minerals, rocks and fossils), geomorphological (landforms and processes) and pedological variables. This concept has been widespread and consolidated in scientific circles, where early studies focused on methods that assessed the spatial variability of the geodiversity, with a particular focus on quantitative aspects. In this study, a geodiversity quantification methodology (Pereira et al. 2013) has been applied to the Xingu River basin (Amazônia, Brazil), which covers approximately 51 million hectares. This methodology is based on measuring and integrating abiotic elements, which are spatialised using thematic maps at scales varying between $1: 250,000$ and $1: 1,000,000$ and using a 1:25,000 systematic linkage grid. This methodology was adapted for the Amazonian environment by including parameters related to river channel patterns, as approximately $12.6 \%$ of the area is a fluvial environment (channels and floodplains). After applying the methodology, geodiversity indices varying between 4 and 32 were obtained, and a geodiversity hot spot in the basin was identified in the region known as "Volta Grande do Xingu" (The Great Bend of the Xingu). The results of the study highlight the fragility of legal tools for environmental protection of the area, primarily those related to aspects of the
\end{abstract}

J. de Paula Silva $(\bowtie) \cdot C$. Rodrigues

Department of Geography, University of São Paulo,

São Paulo, Brazil

e-mail: julianadepaula@yahoo.com

C. Rodrigues

e-mail: cleidrig@usp.br

D. I. Pereira

Earth Sciences Department, University of Minho, Braga, Portugal

e-mail: insuad@dct.uminho.pt physical environment. Although large portions of the basin are partially or fully protected (as indigenous lands and conservation units), the area with the greatest geodiversity is precisely the one which has fewer legal protection devices and is where the Belo Monte hydroelectric power plant is being built.

Keywords Geodiversity assessment · Xingu River . Amazonia

\section{Introduction}

The concept of geodiversity succeeds that of biodiversity, which became widespread after the signing of the Convention on Biological Diversity at the Earth Summit held in Rio de Janeiro in 1992 (Serrano and Ruiz-Flaño 2007). The present importance of geodiversity stems from renewed interest in the conservation of abiotic elements of the natural environment over the last two decades (Bruschi 2007; Hjort and Luoto 2010).

Today, there is a revived interest in geodiversity and the conservation of the abiotic environment that is generally based around the concepts of geological heritage and geomorphological heritage. The term "geodiversity" first appeared in the work carried out in Tasmania by Sharples (1993), Kiernan (1996, 1997), and Dixon (1995). Gray (2004) defines geodiversity as "the natural range (diversity) of geological (rocks, minerals, fossils), geomorphological (land form, processes) and soil features. It includes their assemblages, relationships, properties, interpretation and systems". More recent definitions of geodiversity, such as the definition proposed by Serrano and Ruiz-Flaño (2007), include forms resulting from anthropogenic processes and also topography and elements of the hydrosphere.

After 20 years of discussion and refinements, the term geodiversity is currently considered to be the expression of 
the assemblage of aspects related to the abiotic environment, which include the lithological, stratigraphic, mineralogical and tectonic characteristics of an area, as well as its geomorphological, pedological and palaeontological characteristics. Despite the concepts of geodiversity and geological heritage being independent, they are often linked together when considering objectives for nature conservation and land management. The second concept relates only to remarkable cases of geodiversity observed from a scientific, didactic or scenic perspective. Moreover, if the term biodiversity contains the concept of a heritage value, the same is not true regarding the concept of geodiversity; the value of which is associated, in general, to a usage value or resource value.

If this concept is accepted, then a move towards quantitatively assessing the spatial variability of geodiversity is required. There are only a few studies on this subject (Ruban 2010).

The following are some notable research examples focused on this aspect:

- Kozlowski (2004) assessed the geodiversity in the southern sector of Poland, emphasising relief dissection;

- The study by Carcavilla Urqui et al. (2007) was based on the variety, frequency and distribution of geological classes;

- Serrano and Ruiz-Flaño (2007) considered the number of physical elements (geomorphology, hydrology and soils), roughness coefficient and the surface of each unit;

- Benito-Calvo et al. (2009) used morphometric, morphoclimatic and geological maps that were classified and combined using a geographic information system (GIS);

- Hjort and Luoto (2010) systematically inventoried geodiversity elements (number of elements, genesis, formation time and index proposed by Serrano and RuizFlaño 2007) using a $500 \times 500 \mathrm{~m}$ grid, and compared the index obtained with the topography of the area;

- Ruban (2010) proposed 21 types of geosites, defining geodiversity as the number of types of geosites in a given territory, "geoambundance" as the number of geosites in a given area and "georichness" as the sum of the previous two indices;

- Zwoliñski (2010) also used a geographic information system to develop three maps: landform energy, landform fragmentation and landform preservation; these maps are correlated to create a synthesised geodiversity map with five classes: very high, high, medium, low and very low;

- Pellitero et al. (2011) evaluated the geodiversity in the Ebro and Rudron Gorges Natural Park based on the method developed by Serrano and Ruiz-Flaño (2007). Besides the use of geomorphological units, this method takes into account the habitat units in order to obtain a more detailed spatial division in the evaluation of geodiversity.
- Pereira et al. (2013) counted the number of different types of geodiversity elements using a $25 \times 25 \mathrm{~km}$ grid and defined a geodiversity index. The methodology was applied to the State of Paraná (Brazil) and resulted in the preparation of a geodiversity value map, where geodiversity hotspots were highlighted in relation to areas of medium and low levels of geodiversity.

The present work was developed based on the methodology of Pereira et al. (2013) and was applied to the Xingu River basin (Amazonia, Brazil), using a technique of automatic processing of cartographic information.

\section{Study Area}

The Xingu River basin is located between latitudes $01^{\circ}$ and $15^{\circ}$ south and longitudes $50^{\circ}$ and $55^{\circ}$ west in the states of Pará and Mato Grosso, the last is where its sources are located. The Xingu River is approximately $2,600 \mathrm{~km}$ long and is one of the right margin tributaries of the Amazon River. The area of this basin corresponds to $13 \%$ of the Amazon Basin within the Brazilian territory (Eletrobras 2009). The total area of the Xingu Basin covers 51.1 million hectares: 17.7 million in Mato Grosso and 33.4 million in the state of Pará. Of this total, it is estimated that 30.5 million hectares are legally protected from deforestation, divided into 28 indigenous territories and 18 conservation units (SEFAZ-MT 2009).

Although much of the Xingu River basin is largely preserved (Fig. 1), the largest deforested areas are located in the upstream portions of the basin, situated in the State of Mato Grosso, due to the cattle ranching activity and soybean monoculture, and in the surroundings of the Trans-Amazonian Highway (State of Pará), specifically in the municipalities of Senador José Porfirio, Vitória do Xingu, Altamira, Brasil Novo and Medicilândia. In this case, the presence of logging and cattle ranching are the main economic activities linked to deforestation.

In an area known as Volta Grande do Xingu (The Great Bend of Xingu), where the Xingu River exhibits three bends near the city of Altamira, a hydroelectric power plant is currently being built, the Belo Monte Power Plant, which will be the third largest in the world.

The estimated area to be cleared to construct the plant is $516 \mathrm{~km}^{2}$ (ELETROBRAS 2009), and the river's natural course will be diverted, which will reduce its flow over a 100-km stretch (Eletrobras 2009). The construction work will significantly impact the area from a biotic, abiotic and cultural perspective.

The study area covers two macro-structures: the Archean and Proterozoic Amazonian Craton and the Phanerozoic cover. 


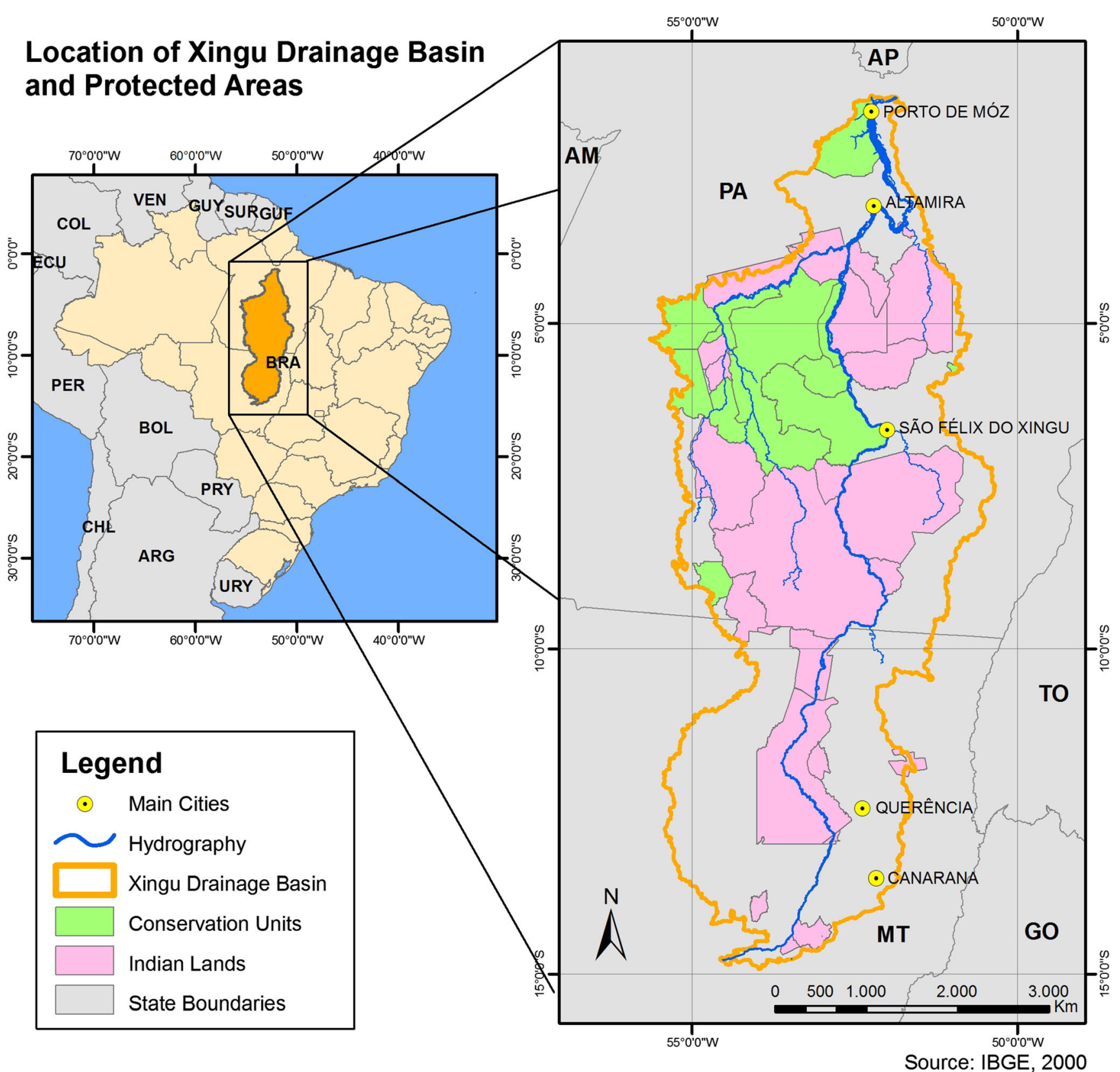

Fig. 1 Location of the study area and distribution of the special areas (conservation units and indigenous land)

The Amazonian Craton, which comprises a wide area beyond the Xingu basin, is known locally as the Xingu Complex. In general, the Xingu Complex consists of gneisses, migmatites, amphibolites, ultrabasic rocks and clastic folded rocks in addition to numerous granitoids, including granodiorite, diorite and gabbro (Schobbenhaus et al. 1984).

The Phanerozoic cover includes parts of the sedimentary basins of Paraná, of Parecis in the upper sector of the Xingu River basin and the sedimentary basin of the Amazon on the lower course of the Xingu River. These basins comprise Paleozoic and Mesozoic sediment. During the Cenozoic Era, neotectonic activity occurred in the Amazon region, strongly related to the Andean uplift, changing the drainage systems and reworking older rock through erosion.

There are 18 fossiliferous units, with six in the Amazon Sedimentary basin, eight in the Paraná Sedimentary basin and one in the Parecis Sedimentary basin, in addition to three units in the Precambrian complexes (Fig. 2).

The Xingu River rises in Chapada dos Guimarães (Guimarães Tableland) at an altitude of approximately $800 \mathrm{~m}$. The relief of the basin is composed mostly of depressions and residual plateaux in various structures with low 


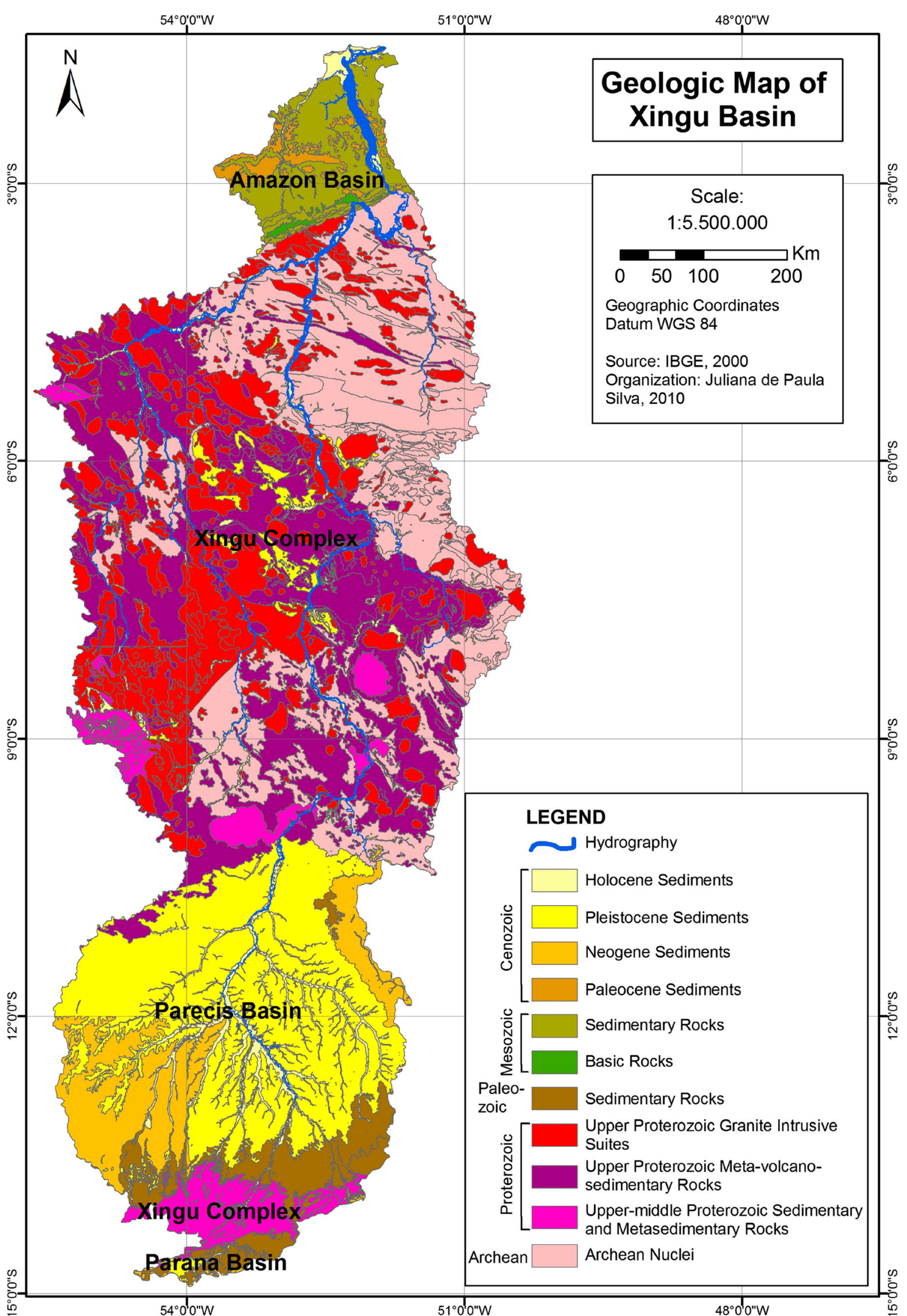

Fig. 2 Geology of the Xingu basin 
dissection. There are also more dissected residual plateaus and ridges with more resistant lithologies, where the highest declivities and altimetries in the basin are found. In the area where the Xingu Complex meets the Amazon Basin, there is a plateau with an extremely high level of dissection and a large hydropower potential, which is where the Belo Monte hydroelectric plant is being built (Fig. 3).

The drainage exhibits dendritic patterns in sedimentary areas and has a strong structural control, with the presence of many rapids in the most dissected portions of the Xingu Complex.

The predominant soils in the basin are Ferralsols and Acrisols in addition to Cambisols, Leptosols, and Lixisols; rocky outcrops are found in the more dissected areas; Gleysols and Fluvisols are found near the watercourses. There are also records of Arenosols and Nitosols.

Recorded minerals include metallic minerals, such as iron, lead, tin, nickel, manganese, pyrite, tungsten, vanadium and titanium; non-metallic minerals, such as phosphorus, fluorspar, fluoride, chromium, charcoal and asbestos; and precious and semi-precious stones, such as aquamarine, citrine quartz, amethyst, gold garnet, diamond, topaz and tourmaline. Lastly, some construction materials include limestone, clay, sand, slate and granite.

\section{Methodology}

The maps were produced using ArcGIS 9.3 Geographic Information System (GIS) software and adopting the proposal presented by Pereira et al. (2013) as a methodological reference.

In this proposal, the authors used small-scale (from $1: 600,000$ to $1: 3,000,000)$ preexisting maps for the state of Paraná (Brazil), which included variables considered to be indicative of geodiversity in accordance with Gray's (2004) definition (e.g., landforms, rocks, soils, mineral resources and fossil records).

In order to obtain the geodiversity index, Pereira et al. (2013) divided the state area (approximately $200,000 \mathrm{~km}^{2}$ ) into 371 equal squares using a $25 \times 25-\mathrm{km}$ grid. The number of occurrences of geological, geomorphological, pedological and palaeontological units was measured within each square. The methodology also evaluated quantitatively the importance of the boundaries of geomorphological units, the hydrography and the existence of minerals, thermal waters and geological energy resources. Counting the number of various units and occurrences allowed five partial diversity indices to be defined (Pereira et al. 2013):

- Geological diversity index, which corresponds to the number of lithological or stratigraphic units represented on a 1:3,000,000 geological map.
- Geomorphological diversity index, which is the sum of the relief and hydrographic sub-indices; the relief subindex results from counting the number of morphosculptural sub-units and the first- and second-order structural contacts, represented on a 1:3,000,000 map of geomorphological units; the fluvial hierarchy index value (Strahler 1957) divided by two is used for the hydrographic sub-index.

- Pedological diversity index, which corresponds to supergroups represented on a 1:3,000,000 pedological map.

- Palaeontological diversity index, which corresponds to the number of palaeontological units represented on a 1:3,000,000 palaeontological map.

- Mineral resource diversity index, obtained from counting the occurrence of different industrial minerals, precious stones and metals, metallic minerals, industrial energy, and mineral and spring water sources represented on a 1:3,000,000 geological resources map. Given the difficulty of directly assessing the mineralogical diversity, it is understood that the mining activity is a good indicator. Attending to the purpose of provide tools for environmental management, mining activity provides relevant data to be included.

Finally, the partial indices were summed to obtain the geodiversity index assigned to each grid square. These values allowed the preparation of an isoline map of geodiversity indices.

Using this methodology, all geodiversity components received an approximate weight without overvaluing a single element, which has been a common problem in assessment methodologies used to date. The intention was to represent all components holistically by quantifying the full range of abiotic diversity (Carcavilla Urqui et al. 2007; Serrano and Ruiz-Flaño 2007).

In the present work, we used a systematic cartographic linkage grid on a $1: 25,000$ scale, which generated 2,462 squares with an approximate area of $13.8 \mathrm{~km}^{2}$ that covered the entire Xingu River basin. Each square within the river basin contains the values for each variable that were assigned according to Pereira et al. (2013). The procedure was performed automatically using the ArcGis 9.3 software, following the methodology presented by Silva et al. (2013). This procedure was used in order to optimise this methodology. The preparation time for the final geodiversity index map was thereby considerably reduced, which allows the methodology to be applied to a large area, such as the Xingu River basin.

The cartographic sources used were digital bases on a 1:250,000 scale (IBGE 2000) for the geology, palaeontology and geomorphology themes, digital bases on a scale of 1:1,000,000 (IBGE 2003) for pedology and the digital base from the Geological Survey of Brazil (CPRM 2004, 2008) for mineral occurrences. This map serves as a basis for territorial 


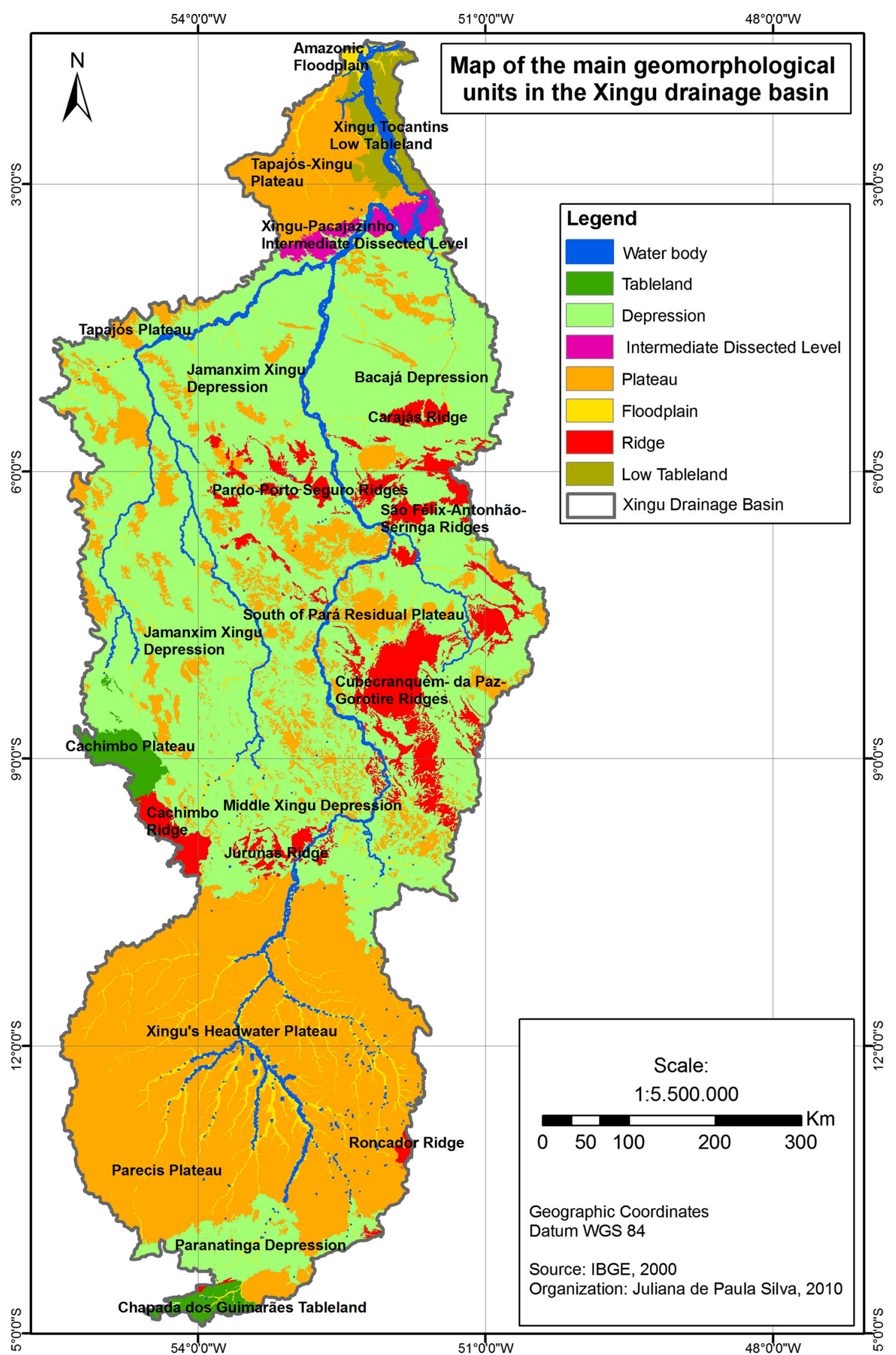

Fig. 3 Map of the main geomorphological units in the Xingu drainage basin 
planning. The optimisation of operational procedures is critical to disseminating the methodology.
Figure 4 shows how the weights were assigned to each partial index in a zoomed area with a high geodiversity.
Localization of the "zoom area" on the Index of Geodiversity Map

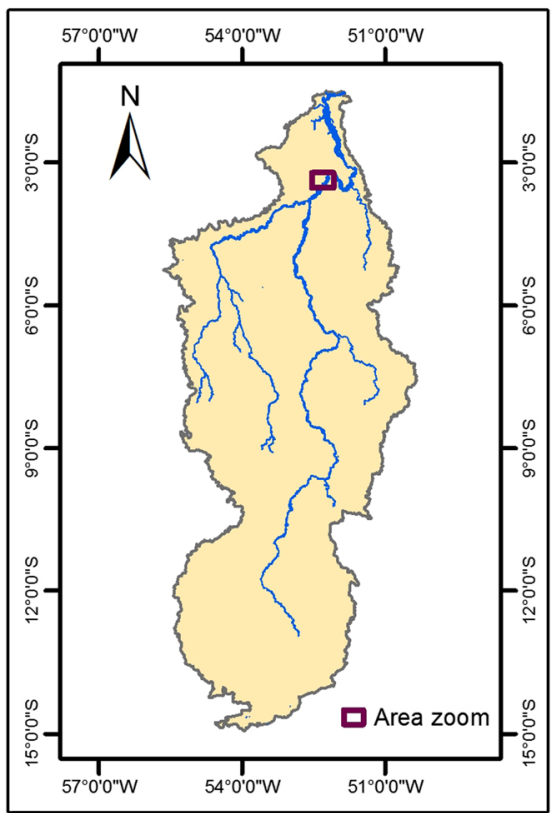

(E) Changes in Channel Pattern

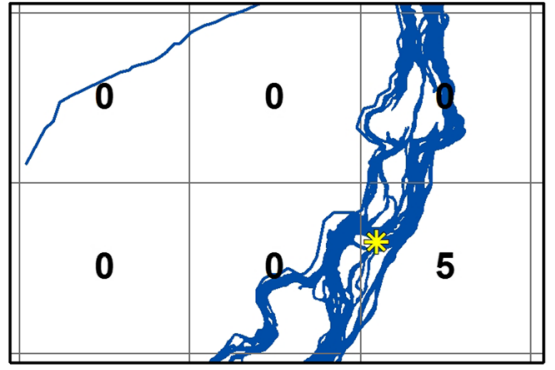

(H) Paleontological Index

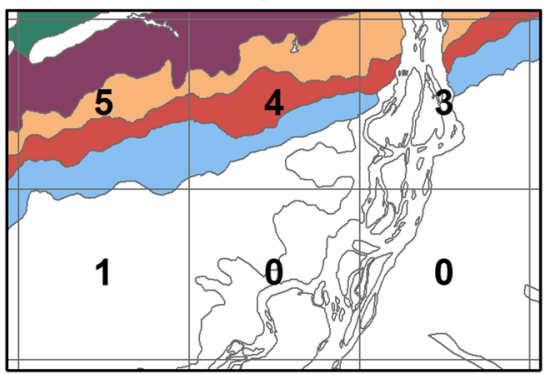

(A) Geological Index

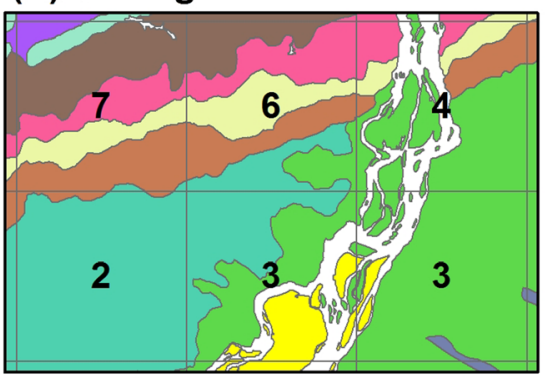

(C) Structural Contacts

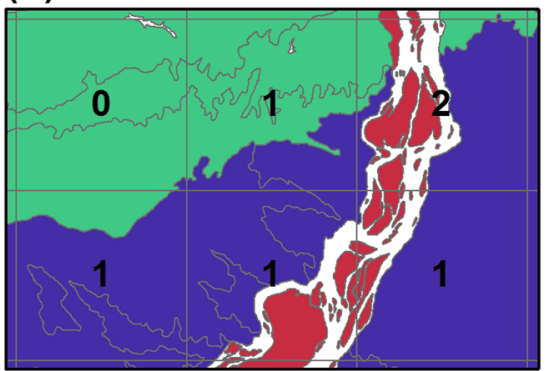

(F) Geomorphological Index

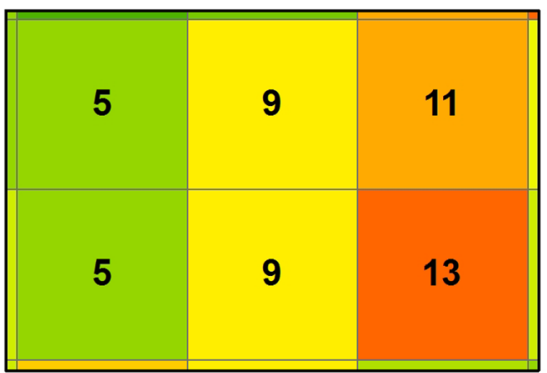

(I) ) Mineral Occurrences Index

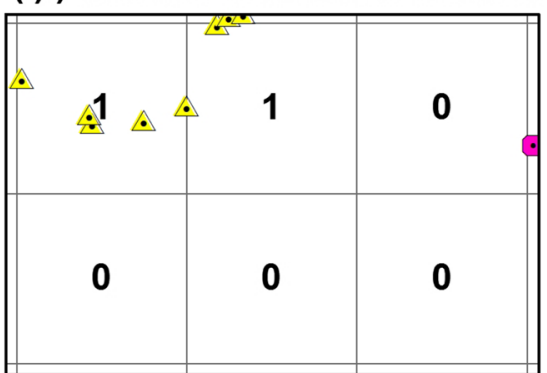

(B) Geomorphological Units

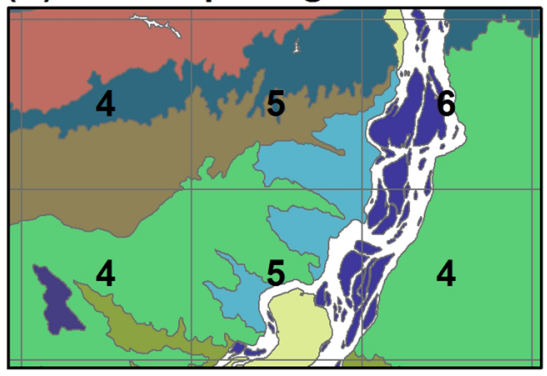

(D) Hydrography

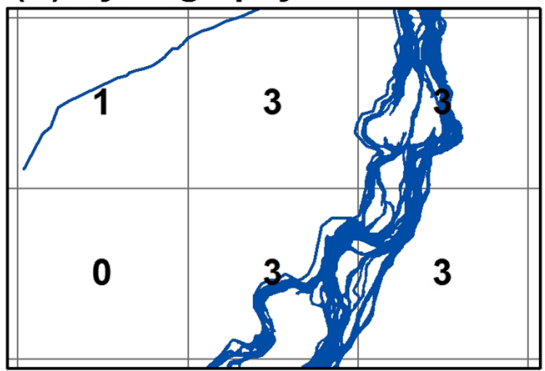

(G) Pedological Index

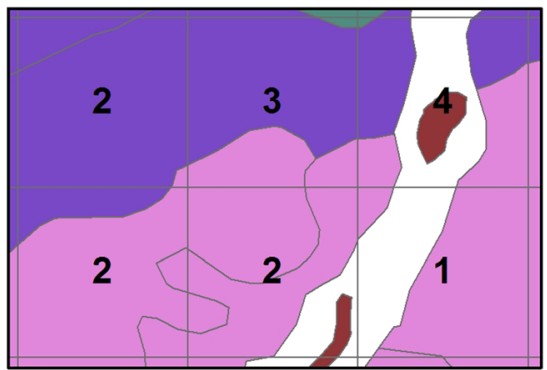

(J) Geodiversity Index

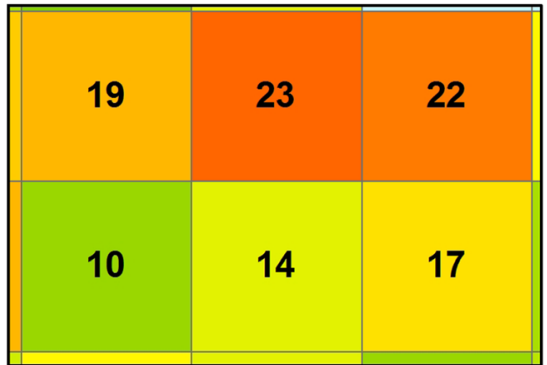

Fig. 4 Example of the partial and full geodiversity indices in a high geodiversity area in the Xingu River basin a geological index: sum of the geological units represented by different colours $\mathbf{b}$ geomorphological units: the sum of geomorphological units represented by different colours $\mathbf{c}$ structural contacts: a value of 1 is assigned for each structural contact $\mathbf{d}$ hydrography: fluvial hierarchy/2 e changes in channel pattern: one point multiplied by the hierarchy for each changing pattern of the river channels f geomorphological index: sum of the sub-indices of the geomorphological units, structural contacts, hydrography and changes in channel pattern $\mathbf{g}$ pedological index: sum of the occurrences of the soil types represented by different colours $\mathbf{h}$ palaeontological index: sum of the number of units with fossil records (coloured polygons) represented by different colours i mineral occurrences index: number of different occurrences in each square; the symbols represent different mineral resources and geological energy resources $\mathbf{j}$ geodiversity index: sum of the geological, geomorphological, pedological, palaeontological and mineral occurrences indices 


\section{Results}

Using the adopted methodology, based on the counting of the geodiversity components with the aid of a 1:25,000 systematic linkage grid, the following indices were obtained:

\section{Geological Diversity Index}

This index ranges from 1 to 7, wherein the greatest diversity indices were observed in the area corresponding to the Xingu Complex, which is where there is a great diversity of rocks from the Archaean and Proterozoic ages, such as granitic

\section{(A) Geological Index}

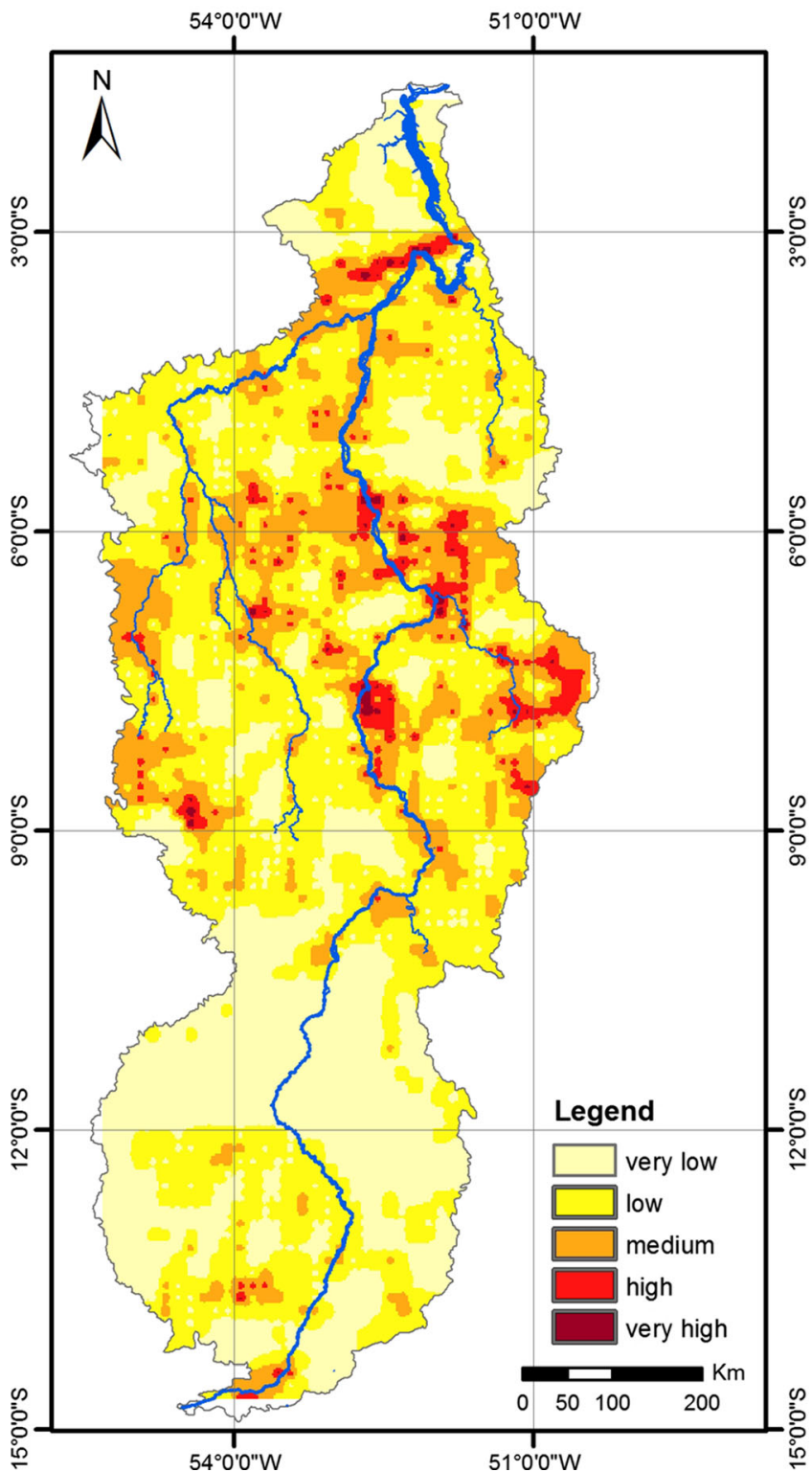

suites, metasedimentary and meta-volcano-sedimentary rocks, and metamorphic rocks of various grades.

Despite the lack of detailed studies in the Xingu River basin, it can still be stated that the great lithostructural diversity in the Xingu Complex is derived from the regional geological processes described by Schobbenhaus et al. (1984). According to these authors, after the consolidation of the Amazonian Craton in the Mesoproterozoic and early Neoproterozoic eras, three important reactivation events occurred, along with intense magmatism and the formation of sedimentary covers: the Uatumã, Parguazense and Rondoniense events. The Uatumã event started approximately $1,900 \mathrm{Ma}$, along with acid to intermediate

\section{(B) Geomorphological Index}

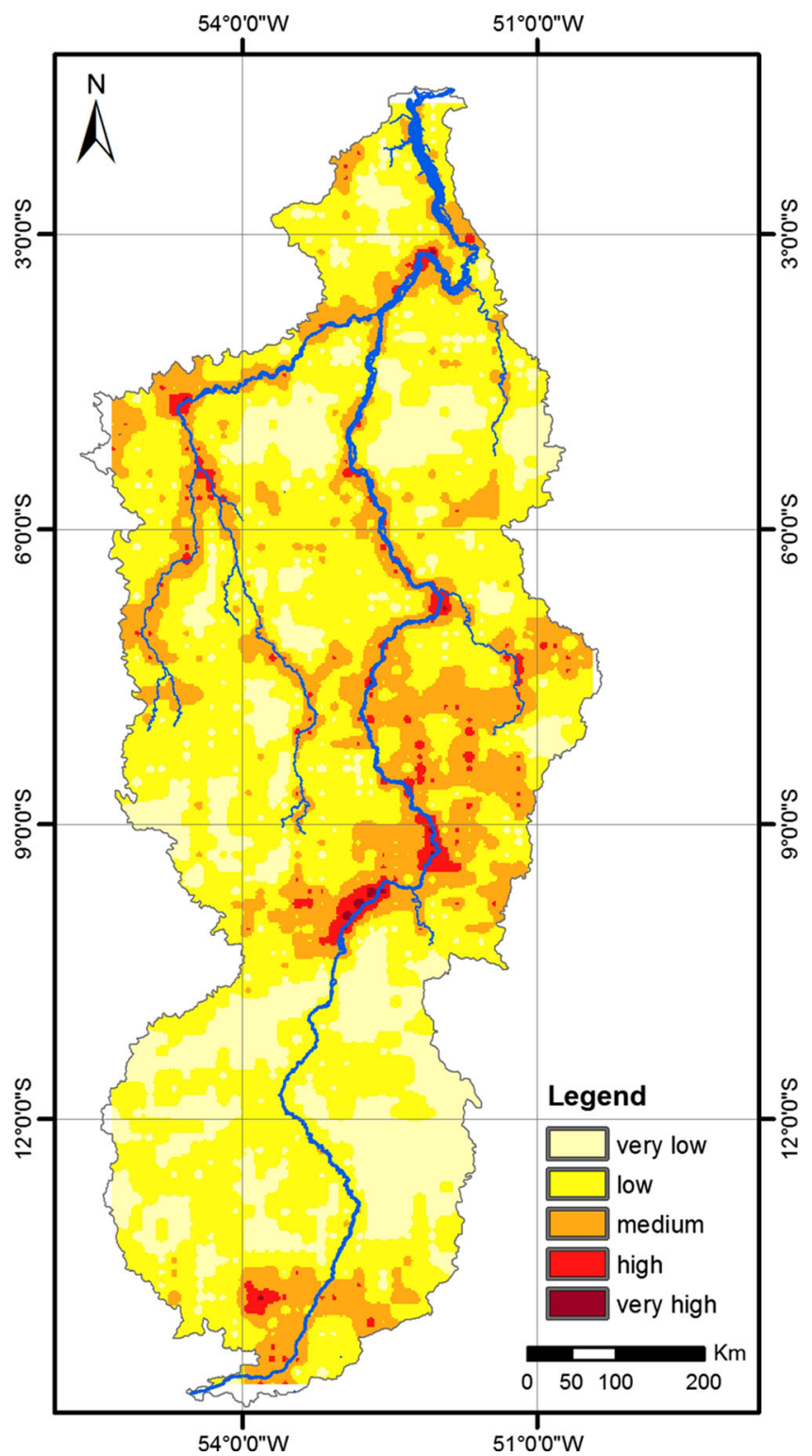

Fig. 5 The values of the geological index a ranges from 1 to 7, and the geomorphological index $\mathbf{b}$ ranges from 2 to 14 . The values of the 2,462 points were interpolated and divided into five classes of equal intervals 
volcanism in large proportions, associated with anorogenic granites. Juliani et al. (2008) asserted that the Uatumã magmatic event represents one of the most important Paleoproterozoic felsic magmatism phases in the world. The volcanic rocks associated with this magmatism cover more than $1,100,000 \mathrm{~km}^{2}$ and represent approximately $30 \%$ of the rocks in the Amazonian Craton, excluding the Phanerozoic basin of the Amazon River. Between 1,600 and 1,700 Ma, this volcanic-plutonic association was covered by an extensive sedimentary cover, with pyroclastic interbedding of continental origin and locally of marine origin. A second generation of anorogenic granites occurred during the Parguazense reactivation $(1,500-1,600 \mathrm{Ma})$; in the Xingu Complex,

\section{(A) Pedological Index}

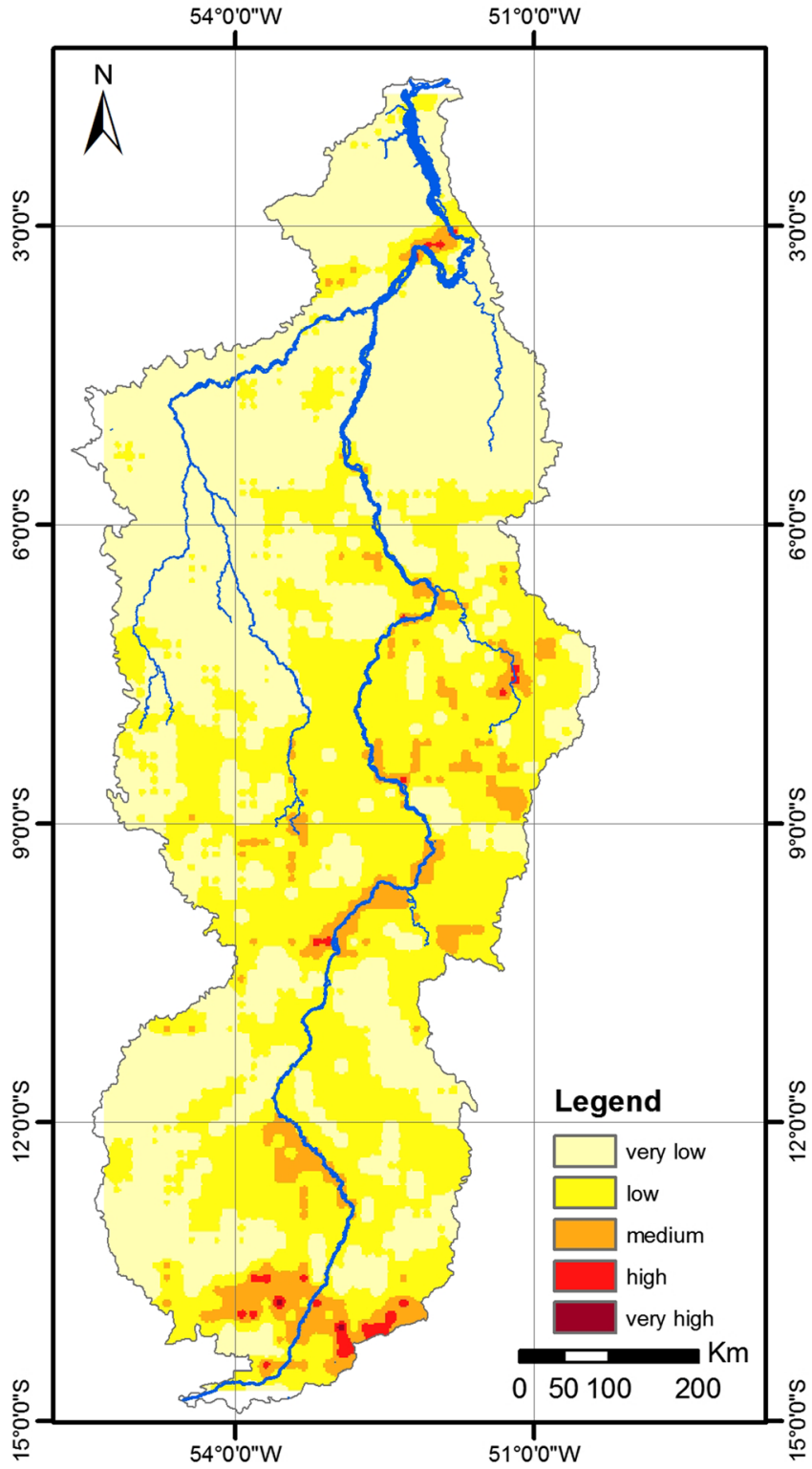

these granitoids are partially covered by continental sediments. In the last event, named Rondoniense $(1,000$ 1,300 Ma), tensional and shearing forces caused the reactivation of faults, which conditioned the formation of acid volcanic rocks.

From the late Rondoniense event until the Brasilian cycle closure, the Amazonian craton behaved as an orthoplatform, which locally showed evidences of reflex activation indicated by the occurrence of diabase dykes from approximately $500 \mathrm{Ma}$ (Schobbenhaus et al. 1984).

A geodiversity "hot spot" is highlighted where the Xingu Complex meets the Amazon sedimentary basin, where there are outcrops of rocks of various ages and types. A trend can

\section{(B) Mineral Occurrence Index}

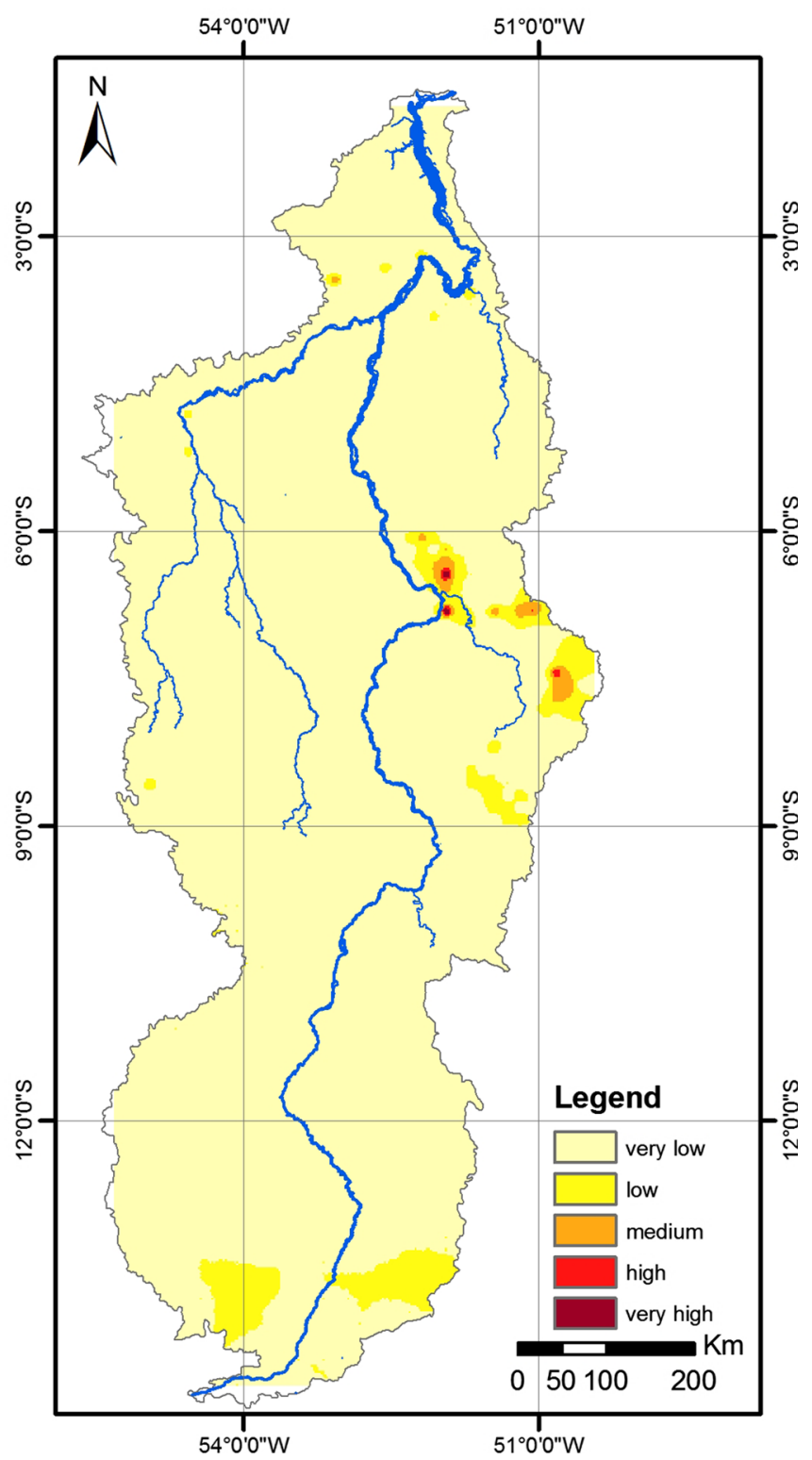

Fig. 6 Pedological index values a range from 1 to 5 , and the mineral occurrence index values $\mathbf{b}$ range from 0 to 5 . The values of the 2,462 points were interpolated and divided into five classes of equal intervals 
also be observed in the occurrence of high levels of diversity near large rivers, where fluvial erosion has exposed a wider variety of rocks and fluvial processes have generated more recent geological units, such as Tertiary and Quaternary alluvium. The sedimentary basin areas farthest away from major watercourses were those that had the lowest indices of geological diversity (Fig. 5a).

\section{Geomorphological Diversity Index}

This index ranges from 2 to 14 , wherein the highest values were near large rivers due to the fact that one of the subindices was based on fluvial hierarchy and another considered the changes in the pattern of river channels. This last element was added to the methodology described by Silva et al. (2013) because it is an abiotic aspect of the utmost importance in the Amazon region, as discussed by Silva (2012). For each change of channel pattern, one point was added and multiplied by the river hierarchy on the site.

This index was also high in ridge landforms and residual plateau areas, particularly when located near large rivers, such as in the case of the Jurunas, Cubencranquém/da Paz/Gorotire and São Félix/Antonhão/Seringa Ridges and the Tapajós Plateau (Fig. 5b). The ridges are developed from sequences of folded and faulted metamorphic and/or metasedimentary rocks, comprising well-dissected landforms and also karst landforms developed from carbonate rocks, which present varying degrees of deformation. In the Tapajós Plateau, the landforms are developed from Archean-proterozoic crystalline rocks corresponding to craton areas, median massive crustal blocks and lowered orogenic belts. The Plateau is characterised by flattened land surfaces and landforms dissected in a homogeneous pattern and occasionally in a differential pattern (IBGE 2000).

\section{Pedological Diversity Index}

Because a less-detailed cartographic base was used, the pedological diversity index showed less variation (from 1 to 5). Large areas with little soil diversity, predominantly Ferralsols and Acrisols, were identified. The areas with the greatest diversity occurred where the Xingu Complex meets the Amazon basin to the north and where the Xingu Complex meets the Parecis and Paraná basins to the south. In both cases, the great diversity of geomorphological and geological elements influences the development of a greater soil diversity.

There are Plinthosols, Leptosols, Arenosols, Lixisols and Cambisols in these areas, along with ferralsols and acrisols. There also occurs an increase in the soil diversity near large rivers, where the soil water regime leads to the formation of hydromorphic soils, such as Gleysols, and where the fluvial deposition of recent sediments generates Fluvisols (Fig. 6a).
Mineral Resources Diversity Index

This index ranges from 0 to 5 . The highest values were found in the regions of the São Félix/Antonhão/Seringa Ridges and the Cubencranquém/da Paz/Gorotire Ridges near the city of São Félix do Xingu, where metallic mineral resources, such as gold, titanium, tin, chromium, lead and vanadium, predominate, besides fluorine. Higher values are also present in the area where the Amazon basin and the Xingu Complex meet, in the northern basin, where deposits of gold, manganese, tin, limestone and phosphorus occur, as well as extraction of sand and clay. There are also areas of greater diversity in the

\section{Paleontological Index}

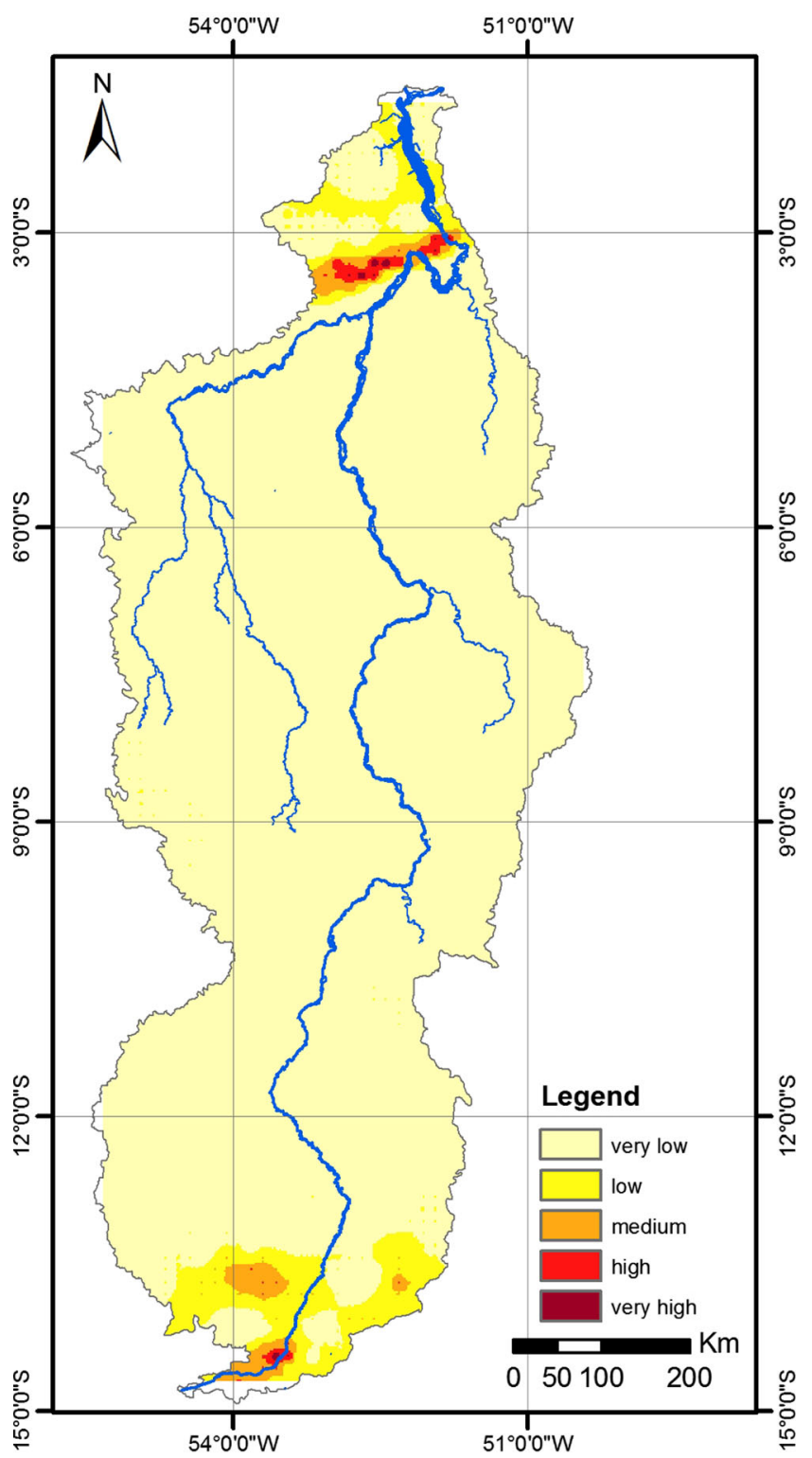

Fig. 7 Palaeontological index values range from 0 to 5 . The values of the 2,462 points were interpolated and divided into five classes of equal intervals 
southern basin, where diamond deposits and clay extractions are found.

In this context, it is worth noting that the diversity indices obtained are probably much lower than the real diversity that exists in the basin, since there is a high degree of restriction in the indigenous areas and conservation units. The Brazilian Constitution does not allow the search for or exploitation of mineral resources in these special areas (Fig. 6b). In addition, sources of mineral water and springs were not considered because they were not included in the mapping of mineral resources used.

It is also worth mentioning that the mineral resource itself is not an element of geodiversity, but it was used as an indicator of mineral diversity in the applied methodology, as minerals are one of the geodiversity elements according to Gray's (2004) definition, as adopted in this study.
Palaeontological Diversity Index

The palaeontological index ranges from 0 to 5 , wherein the areas of greatest diversity were found in the geological formations contained in the Amazon, Paraná and Parecis basins.

Much of the basin is associated with a zero value because crystalline and high-grade metamorphic rocks predominate in these areas (Fig. 7). In addition, there is a great lack of knowledge related to the existence of fossils in the Amazon, and the preservation of fossils is limited by accelerated oxidation processes occurring in the humid tropical environment.

Geodiversity Index

The total geodiversity index ranges from 4 to 32 . A geodiversity hot spot occurs at the boundary between the Xingu Complex and the Amazon basin as the erosional

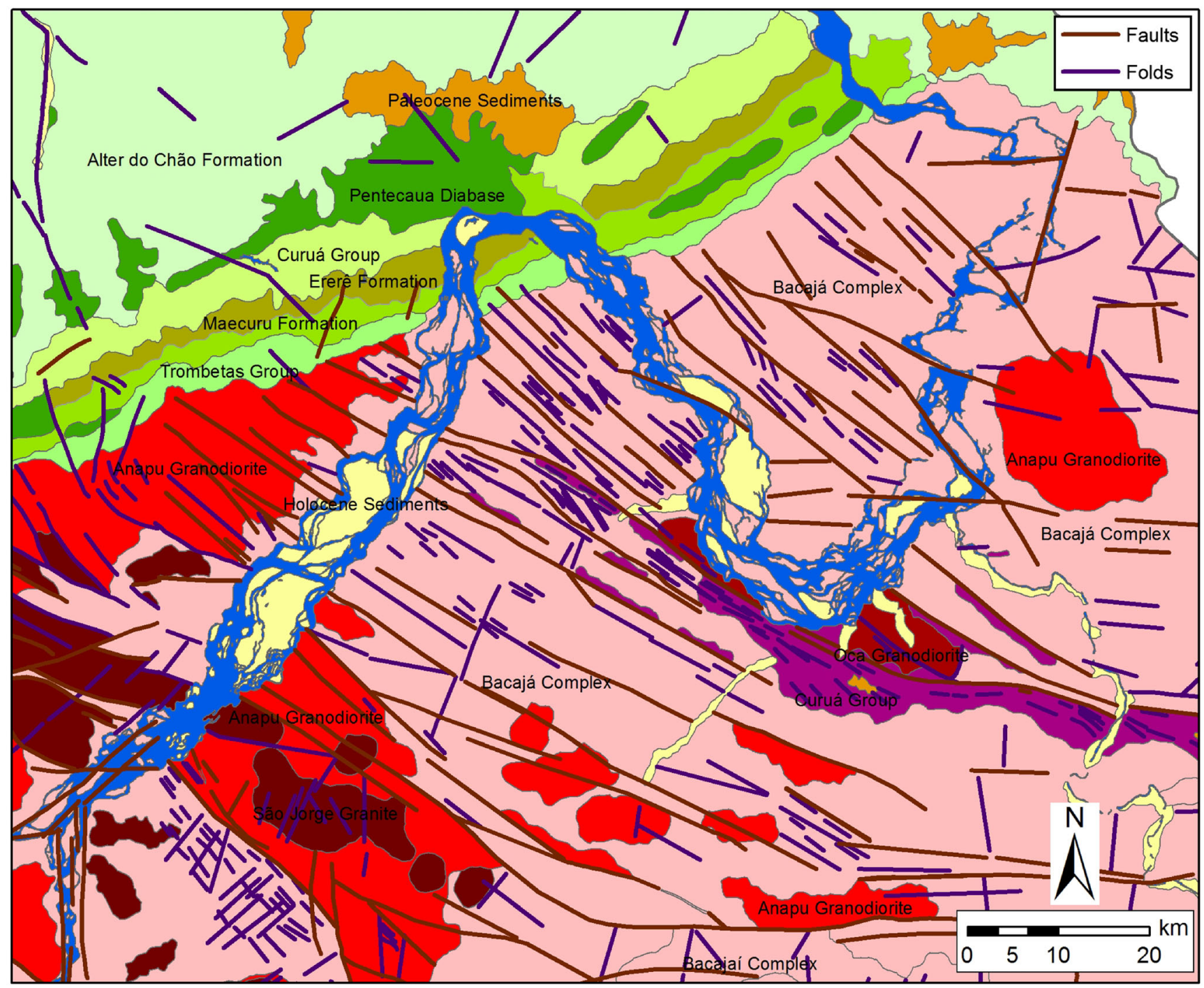

Fig. 8 Portion of the map of geological units in the "Volta Grande do Xingu" region (The Great Bend of the Xingu region) 
processes that occur on the border of the Xingu Precambrian Complex expose a wide variety of resistant lithologies intercalated with sedimentary rocks from the Amazon basin. This lithological complexity has resulted in the occurrence of different types of rock and mineral resources and gives rise to various types of soil and landforms.

The high resistance of the Mesozoic Pentecaua diabase to erosion (Fig. 8) produced the first inflection in the main river channel, after which the river flows through a very faulted and fractured area, forming the "Volta Grande do Xingu" (the Great Bend of the Xingu). This Great Bend is a very peculiar geomorphological feature in a scientific and functional perspective, and this unusual characteristic of the fluvial morphology has led to the presence of 305 of the 467 fish species recorded in all the basin area. Moreover, this area holds a high aesthetic value due to the great number of rapids, the voluminous river flow and the water transparency (Fig. 9), which generate luxuriant natural scenery.

Additionally, there are areas of high geodiversity near the city of São Félix do Xingu, where there are outcrops of ancient rock, diverse landforms and a large number of mineral resources in the region of the São Félix/Antonhão/Seringa Ridges. There is also an area with high geodiversity in the Xingu Headwaters Plateau region, situated in the southern basin, due to the wide variety of rock and landforms and to the presence of sites with high palaeontological potential.

The areas that had the lowest indices were those in the Parecis Basin, followed by the Bacajá Complex region north of the Xingu Complex. In both cases, the level of geodiversity is lower, especially in areas far from large rivers (Fig. 10). In such areas with a low geodiversity, the relief shows little dissection and there is a relative homogeneity of rocks and soils, which results in a more homogeneous landscape and in low values related to the diversity of abiotic elements.

\section{Final Considerations}

Using an automatic procedure allowed a large quantity of information to be generated in a short period of time - when compared to a situation in which the same products are manually formulated. The methodology proved to be appropriate for application in land management because it enabled a rapid, clear visualisation of areas of greater and lesser geodiversity for the basin in question.

It should be noted, however, that cartographic products from official agencies or research institutes, such as geological, geomorphological, pedological, mineral resources and palaeontological maps, were used as a basis for creating the abiotic diversity index maps. New data from future publications in the study area may provide a new distribution in the values of the geodiversity index map; for example, new mineral resources or palaeontological records may be found, as well as soil classifications on a more detailed scale may be developed. In this case, the geodiversity assessment based on preexisting maps and information can evolve as the knowledge of the abiotic aspects of the area is improved.

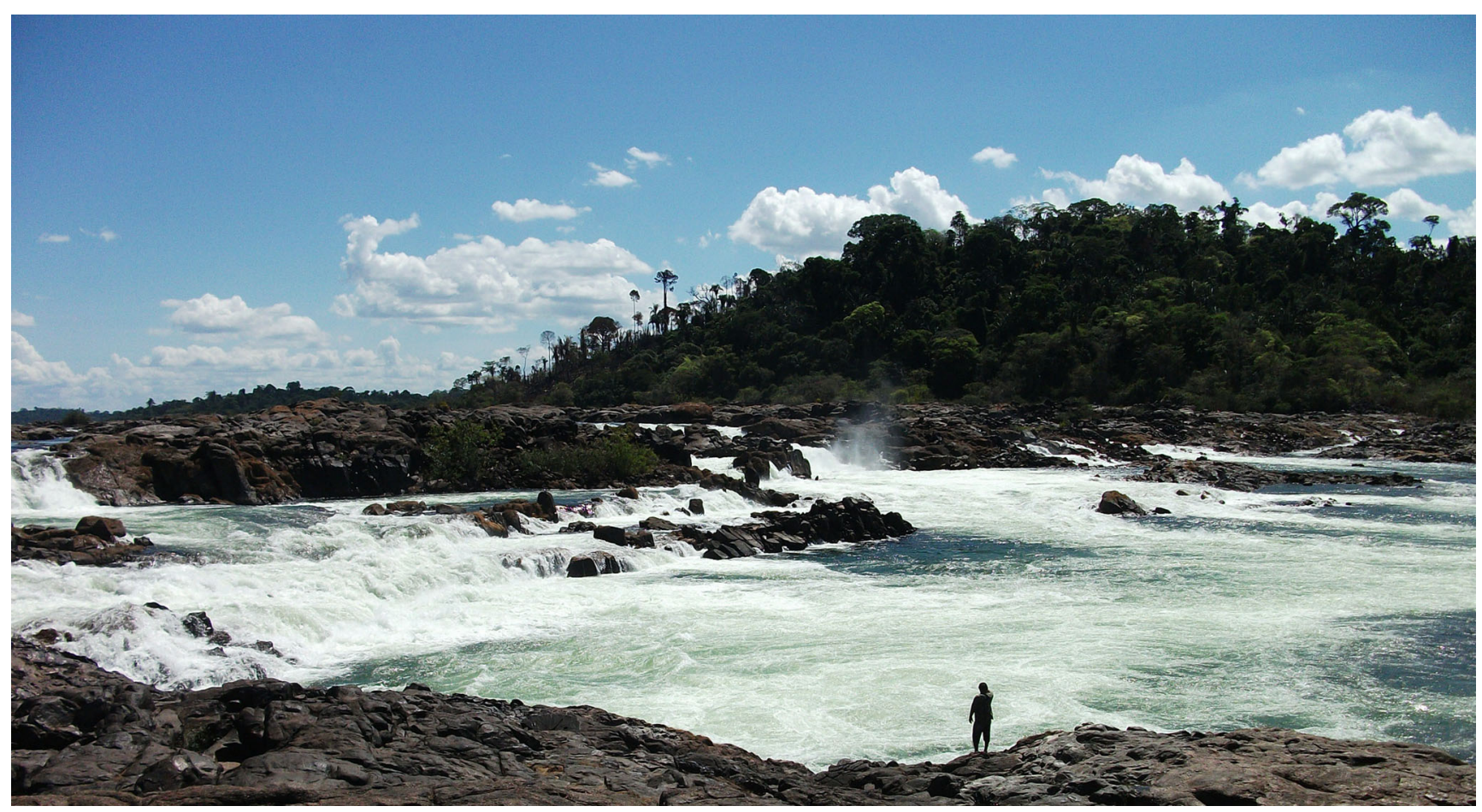

Fig. 9 Area with rapids in the "Volta Grande do Xingu" region (The Great Bend of the Xingu region), which holds high aesthetic value 


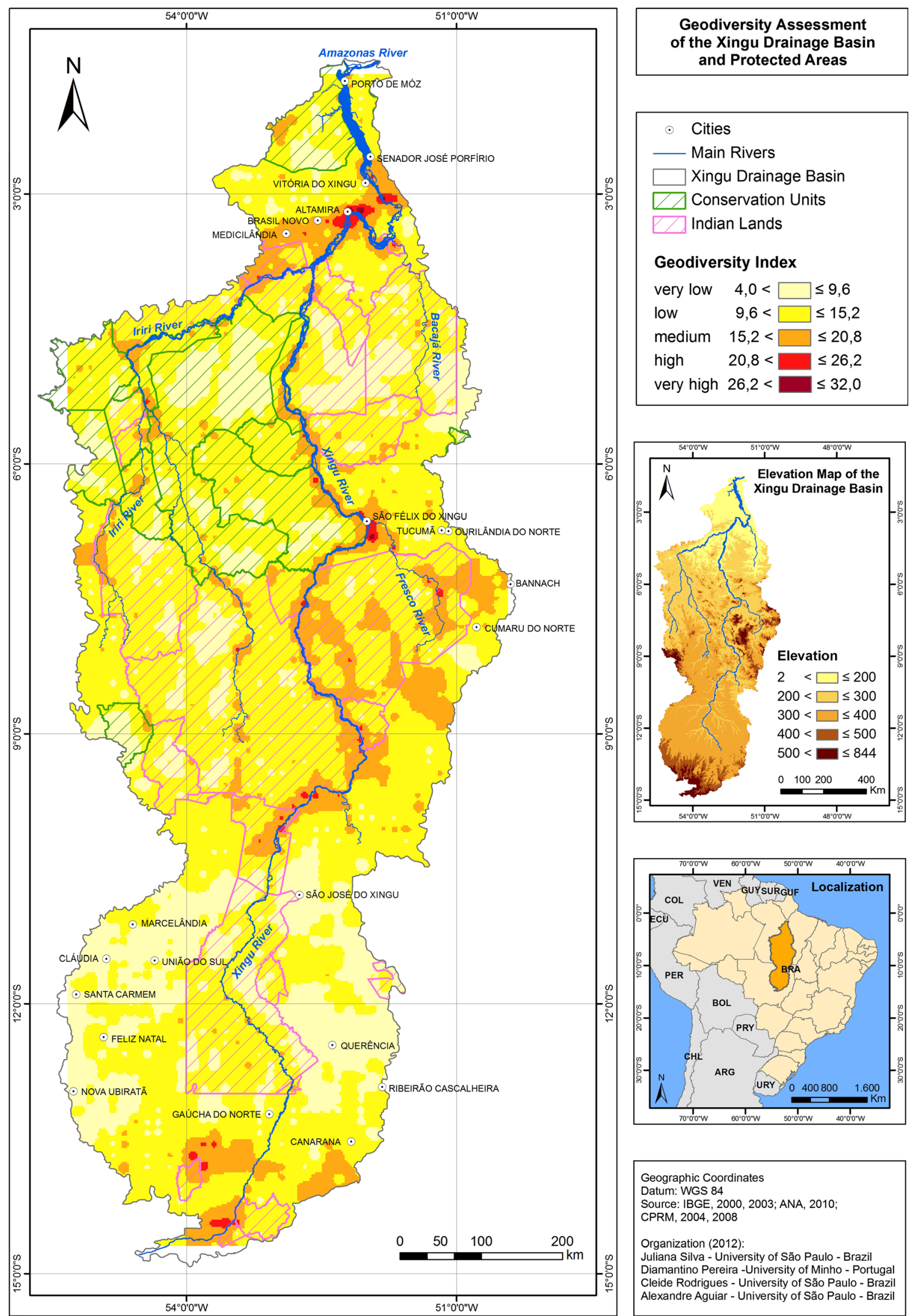

Fig. 10 Geodiversity index values range from 4 to 32 . The values of the 2,462 points were interpolated and divided into five classes of equal intervals 
This study represents another step in the evolution of quantifying abiotic resources in nature, a topic that still requires new proposals and discussions to establish appropriate and effective methods to manage these resources. In the specific case of the Xingu River basin, however, there is no legal protection of any type for the areas with the greatest geodiversity (Fig. 7). It is clear, therefore, that the criteria used in the definition of conservation areas did not account for abiotic issues.

The geodiversity "hot spot" identified is exactly located in the area where the Belo Monte hydroelectric plant is being built (Volta Grande do Xingu). In this case, the abiotic aspect related to the potential for hydroelectric generation will be exploited, but the loss of large areas with fossiliferous, mineral and aesthetic potential will be increased. In addition, relationships between abiotic and biotic aspects, and the relationship between human populations, particularly indigenous ones, and the natural environment will be affected.

It is hoped that this present type of assessment will allow decisions, such as the selection of conservation units or the construction of large works, to be taken more consciouslyfor instance in the context of a proper evaluation of all components in nature (biotic and abiotic), and linked social components, before they are irreversibly affected.

\section{References}

Benito-Calvo A, Pérez-González A, Magri O, Meza P (2009) Assessing regional geodiversity: the Iberian Peninsula. Earth Surf Process Landf 34(10): 1433-1445

Bruschi VM (2007) Desarrollo de una metodología para la caracterización, evaluación y gestión de los recursos de la geodiversidad. 2007. 355f. Tese (Doutorado em Ciências da Terra e Física da Matéria Condensada). Faculdade de Ciências da Universidade de Cantabria, Santander. (in Spanish)

Carcavilla Urqui L, López Martínez J, Durán Valsero J (2007) Patrimonio geológico y geodiversidad: investigación, conservación, gestión y relación con los espacios naturales protegidos. Cuadernos del Museo Geominero 7, IGME, Madrid (in Spanish)

CPRM - Geological Survey of Brazil (2004). State of Mato Grosso Mineral Resource Map. Scale 1:1,000,000. Available at: http:// www.cprm.gov.br/. Accessed on Oct. 2011

CPRM-Geological Survey of Brazil (2008) GIS - Geology and Mineral Resources of the State of Pará. Digital archive in shapefile format. Accessed on Oct. 2011

Dixon G (1995) Geoconservation: an international review and strategy for Tasmania; a report to the Australian Heritage Commission, Occasional Paper No. 35, Parks \& Wildlife Service, Tasmania.

ELETROBRAS (2009) Aproveitamentos Hidrelétricos da Bacia Hidrográfica do Rio Xingu: Relatório de Impacto Ambiental. São Paulo: Eletrobrás. Volume 1. 197 p (in Portuguese)
Gray M (2004) Geodiversity: valuing and conserving abiotic nature. Wiley, Chichester

Hjort J, Luoto M (2010) Geodiversity of high-latitude landscapes in northern Finland. Geomorphology 115:109-116

IBGE-Brazilian Institute of Geography and Statistics (2000) Cartographic base of the tematic mapping of Legal Amazonia (Shapefile format). Available at www.ibge.gov.br. Accessed on Sept. 2008

IBGE-Brazilian Institute of Geography and Statistics (2003). Pedological map of Legal Amazonia (Shapefile format). Available at www.ibge.gov.br. Accessed on Feb. 2007

Juliani C. et al. (2008) A gênese do vulcano-plutonismo Uatumã e das mineralizações de Au e de metais de base associadas nas regiões do Tapajós, Iriri E Xingu (PA). In: Simpósio de vulcanismo e ambientes associados, 4, 2008, Foz do Iguaçu, PR. Anais... Foz do Iguaçu (in Portuguese)

Kiernan K (1996) Conserving geodiversity and geoheritage: the conservation of glacial landforms; Report to the Australian Heritage Commission

Kiernan K (1997) The conservation of landforms of coastal origin: conserving Tasmania's geodiversity and geoheritage: forest practices unit, Hobart, Tasmania, $273 \mathrm{p}$

Kozlowski S (2004) Geodiversity. The concept and scope of geodiversity. Prz Geol 52(8/2):833-837

Pellitero R, González-Amuchastegui MJ, Ruiz-Flaño P, Serrano E (2011) Geodiversity and geomorphosite assessment applied to a natural protected area: the Ebro and Rudron Gorges Natural Park (Spain). Geoheritage 3(3):163-174

Pereira DI, Pereira P, Brilha J, Santos L (2013) Geodiversity assessment of Parana State (Brazil): an innovative approach. Environmental Management, v.52, p.541-522, 2013. Available at http://link. springer.com/article/10.1007\%2Fs00267-013-0100-2. Accessed on Oct. 2013

Ruban D (2010) Quantification of geodiversity and its loss. Proc Geol Assoc 121:326-333

Schobbenhaus C. et al. (1984) Geologia do Brasil: texto explicativo do mapa geológico do Brasil e da área oceânica adjacente incluindo depósitos minerais, escala 1:250.000. Brasília: CNPMDepartamento Nacional de Produção Mineral (in Portuguese)

SEFAZ-MT - Secretaria da Fazenda do Estado do Mato Grosso (2009) Pesquisadores detalham realidade ambiental na bacia do Xingu. Available at http://www.sefaz.mt.gov.br/portal/index.php?action = noti\&codg_Noticia $=10214$. Accessed on May 2009 (in Portuguese)

Serrano E, Ruiz-Flaño P (2007) Geodiversity: a theoretical and applied concept. Geogr Helv 62(3):140-147

Sharples C (1993) A methodology for the identification of significant landforms and geological sites for geoconservation purposes; Report to Forestry Commission, Tasmania

Silva JP (2012) Morfologia fluvial como parâmetro de avaliação de geodiversidade -Aplicação na Bacia Hidrográfica do Rio Xingu. Tese do doutorado. Departamento de Geografia. Universidade de São Paulo, São Paulo

Silva JP, Pereira DI, Aguiar AM, Rodrigues C (2013) Geodiversity assessment of the Xingu drainage basin. J Maps 9:1-9

Strahler AN (1957) Quantitative analysis of watershed geomorphology. Trans Am Geophys Union 8(6):913-920

Zwoliñski Z (2010) The routine of landform geodiversity map design for the Polish Carpathian Mts. Landform Analysis 11:7785 